\title{
Author Correction: Hypericin-based photodynamic therapy induces surface exposure of damage-associated molecular patterns like HSP70 and calreticulin
}

\author{
Abhishek D. Garg ${ }^{1} \cdot$ Dmitri V. Krysko ${ }^{2,3} \cdot$ Peter Vandenabeele ${ }^{2,3} \cdot$ Patrizia Agostinis $^{1}$
}

Published online: 8 May 2018

๑) Springer-Verlag GmbH Germany, part of Springer Nature 2018

\section{Correction to: \\ Cancer Immunol Immunother (2012) 61: 215-221 \\ https://doi.org/10.1007/s00262-011-1184-2}

This correction refers to our Short Communication published in Cancer Immunology Immunotherapy in the year 2012 [1]. It has come to our attention that some errors resulting from accidental oversight concerning incorrect deletion/ replacement of temporary placeholder images during figure assembly and mounting occurred during the assembly of the "Intracellular Proteins" immunoblots presented in Fig. 1a, d.
Using the correct source/raw data, we have now generated the corrected Fig. 1a, d, presented on the next page.

This oversight also led to erroneous duplication of certain intracellular protein lanes presented in Fig. 1a, $d$ in a different paper of ours [2]. These corrections have no influence on the description, interpretation, or the original conclusions of our Short Communication since the intracellular protein data is secondary to the primary focus and conclusions of this Short Communication. However, we would like to apologize for this oversight/mistake and any inconvenience, misunderstanding or confusion this might have caused.
The original article can be found online at https://doi.org/10.1007/ s00262-011-1184-2.

\section{Patrizia Agostinis}

patrizia.agostinis@med.kuleuven.be

1 Cell Death Research and Therapy Unit, Department of Molecular Cell Biology, Faculty of Medicine, Catholic University of Leuven, Campus Gasthuisberg O\&N1, Herestraat 49, 3000 Leuven, Belgium

2 Molecular Signaling and Cell Death Unit, Department for Molecular Biomedical Research, VIB, Ghent, Belgium

3 Department of Biomedical Molecular Biology, Ghent University, Ghent, Belgium 
Fig. 1 Hypericin-PDT-treated cancer cells surface-expose HSP70 and calreticulin but not ERp57. a T24 cells were treated with high PDT dose followed by surface protein biotinylation at $1 \mathrm{~h}$ post-PDT and immunoblotted. b, c T24 cells were treated with high PDT dose, fixed and surface immunostained at $1.5 \mathrm{~h}$ post-PDT for either CRT (b) or HSP70 (c) such that extranuclear fluorescence of residual hypericin was also visualised (scale bar $=20 \mu \mathrm{m})$. d T24 cells were incubated with 100 $\mathrm{nM}$ or $150 \mathrm{nM}$ hypericin for 16 $\mathrm{h}$ and irradiated at a fluency of either 1.35 or $2.16 \mathrm{~J} / \mathrm{cm}^{2}$. This was followed by surface protein biotinylation at $2 \mathrm{~h}$ post-PDT and immunoblotting. CNTR denotes untreated samples. Furthermore, '+BIO' indicates controls exposed to buffer with biotin and '-BIO' indicates controls exposed to buffer without biotin. Representative Western blots are shown for three independent experiments

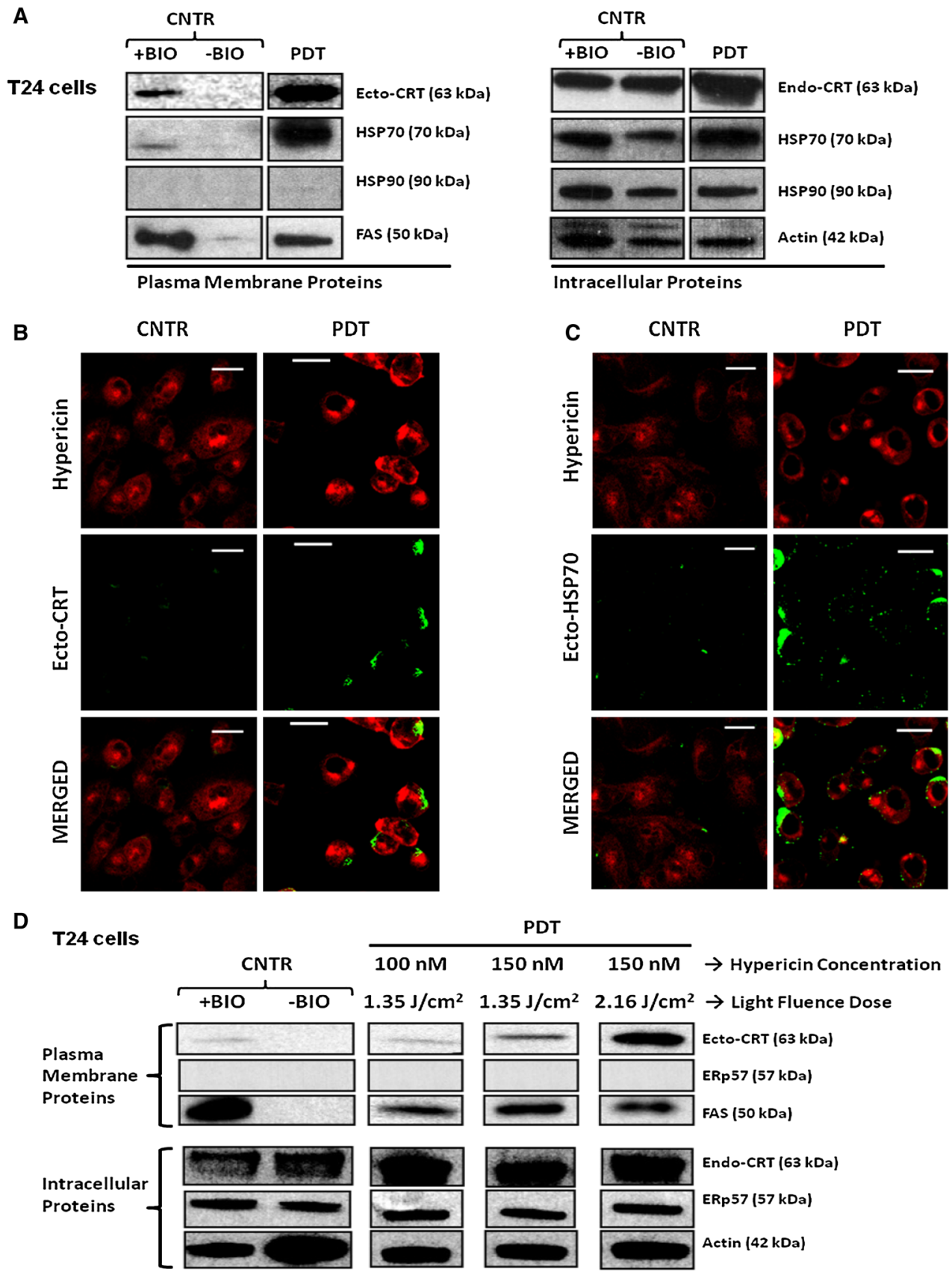

\section{References}

1. Garg AD, Krysko DV, Vandenabeele P, Agostinis P (2012) Hypericin-based photodynamic therapy induces surface exposure of damage-associated molecular patterns like HSP70 and calreticulin. Cancer Immunol Immunother 61:215-221. https:// doi.org/10.1007/s00262-011-1184-2
2. Garg AD, Krysko DV, Verfaillie T, Kaczmarek A, Ferreira GB, Marysael T, Rubio N, Firczuk M, Mathieu C, Roebroek AJM, Annaert W, Golab J, De Witte P, Vandenabeele P, Agostinis P (2012) A novel pathway combining calreticulin exposure and ATP secretion in immunogenic cancer cell death. EMBO J 31:10621079. https://doi.org/10.1038/emboj.2011.497 